\title{
Mewujudkan Sekolah Literasi yang Berprestasi
}

\author{
Sabarudin, M.Pd \\ Ketua Asosiasi Guru Penulis Indonesia Provinsi Kepulauan Bangka Belitung \\ Kepala SMA Negeri 1 Gantung Kabupaten Belitung Timur
}

\begin{abstract}
School culture is the most important factor in shaping students to be optimistic, brave, appearing, cooperative behavior, and personal and academic skills. To optimize the potential of students into an achievement, the right problem solving strategy was chosen, namely through the movement of literacy development to achieve Achievement. The main focus is to empower all school stakeholders in their daily activities by allocating existing educational resources to achieve the achievements and potential of students and realize the vision, mission and goals of the school. Optimizing the potential and achievements of students through the literacy movement can be done with three main principles, namely: (1) The development and strengthening of literacy becomes a movement and real action; (3) Establish communication and synergy with various parties; and (3) Building a shared commitment to optimize the potential and achievements of both academic and non-academic. Seriousness and strong will to make the development and strengthening of literacy as a "joint effort" by building a culture of literacy to prepare information literacy generation, literacy literacy generation, which will be an important component for optimizing the potential and achievement of students as large as must be based on noble goals in developing students' character through acculturing the school literacy ecosystem embodied in the School Literacy Movement $(G L S)$.
\end{abstract}

Keywords : Achievement and Literacy School.

\begin{abstract}
ABSTRAK
Budaya sekolah merupakan faktor yang paling penting dalam membentuk siswa menjadi manusia yang penuh optimis, berani, tampil, berperilaku kooperatif, dan kecakapan personal dan akademik. Untuk mengoptimalkan potensi peserta didik menjadi sebuah prestasi maka dipilih Strategi pemecahan masalah yang tepat, yaitu melalui gerakan pengembangan literasi untuk raih Prestasi. Fokus utamanya yaitu memberdayakan semua stakeholders sekolah dalam kegiatan sehari hari dengan mengalokasikan sumber daya pendidikan yang ada untuk meraih prestasi dan potensi peserta didik serta mewujudkan visi,misi dan tujuan sekolah. Pengoptimalan potensi dan prestasi peserta didik melalu gerakan literasi dapat dilakukan dengan tiga prinsip utama, yakni: (1) Pengembangan dan penguatan literasi menjadi sebuah gerakan dan aksi nyata; (3) Menjalin komunikasi dan sinergitas dengan berbagai pihak; serta (3) Membangun komitmen bersama untuk mengoptimalkan potensi dan prestasi baik akademik maupun non akademik. Kesungguhan dan kemauan yang kuat untuk menjadikan pengembangan dan penguatan literasi sebagai "ikhtiar bersama" dengan membangun budaya literasi untuk menyiapkan generasi melek informasi, generasi melek literasi, yang akan menjadi komponen penting bagi optimalisasi potensi dan prestasi peserta didik yang sebesar besarnya harus didasarkan pada tujuan mulia dalam menumbuhkembangkan budi pekerti peserta didik melalui pembudayaan ekosistem literasi sekolah yang diwujudkan dalam Gerakan Literasi Sekolah (GLS).
\end{abstract}

Kata Kunci : Prestasi dan Sekolah Literasi. 


\section{PENDAHULUAN}

\section{A. Latar Belakang Masalah}

Pendidikan harus lebih berperan dalam membangun seluruh potensi manusia agar menjadi subyek yang berkembang secara optimal dan bermanfaat bagi masyarakat dan pembangunan nasional. Potensi manusia Indonesia yang dikembangkan melalui: (1) Olah hati untuk memperteguh keimanan dan ketakwaan, meningkatkan akhlak mulia, budi pekerti, atau moral, membentuk kepribadian unggul, membangun kepemimpinan dan entrepreneurship; (2) Olah pikir untuk membangun kompetensi dan kemadirian ilmu pengetahuan dan teknologi; (3) Olah rasa untuk meningkatkan sensitifitas, daya apresiasi, daya kreasi, serta daya ekspresi seni dan budaya; serta (4) Olah raga untuk meningkatkan kesehatan, kebugaran, daya tahan, dan kesigapan fisik serta keterampilan kinestetis.

Program unggulan yang diterapkan untuk memaksimalkan potensi peserta didik yaitu "Literasi". Gerakan Literasi di sekolah merupakan wujud komitmen yang kuat dari seluruh komponen sekolah untuk selalu belajar, dan bekerja secara maksimal yang di dorong semangat untuk menjadikan aktivitas membaca, menulis, berkarya, dan berprestasi menjadi satu budaya yang harus digalakkan sekolah. Kesungguhan dan kemauan yang kuat untuk menjadikan gerakan literasi sebagai "ikhtiar bersama" mewujudkan sekolah sebagai organisasi pembelajar yang menjadikan warganya sebagai pembelajar sepanjang hayat dengan membangun budaya literasi di sekolah untuk menyiapkan generasi melek informasi, generasi melek literasi, yang akan menjadi komponen penting bagi peningkatan prestasi peserta didik.

Kegiatan literasi disekolah harus didasarkan pada tujuan mulia dalam menumbuhkembangkan budi pekerti peserta didik melalui pembudayaan ekosistem literasi sekolah yang diwujudkan dalam Gerakan Literasi Sekolah (GLS). Agenda pengembangan literasi disekolah harus diarahkan dalam meningkatkan kapasitas warga dan lingkungan sekolah agar literat, menjadikan sekolah sebagai tempat belajar yang menyenangkan dan ramah anak agar warga sekolah mampu mengelola pengetahuan serta menjaga keberlanjutan pembelajaran dengan menghadirkan beragam buku bacaan dan mewadahi berbagai strategi membaca agar prestasi belajar peserta didik meningkat (Kemdikbud, 2016).

\section{B. Permasalahan}

Permasalahan yang di hadapi adalah :

1. Bagaimanakah pelaksanaan gerakan pengembangan literasi dalam mengoptimalkan potensi dan prestasi peserta didik di sekolah?

2. Apa sajakah yang menjadi kendalakendala dan penerapan gerakan pengembangan literasi dalam 
mengoptimalkan potensi dan prestasi peserta didik di sekolah ?

3. Apa sajakah yang menjadi faktor pendukung penerapan gerakan pengemabngan literasi dalam mengoptimalkan potensi dan prestasi peserta didik di sekolah?

\section{Bagaimanakah} alternatif pengembangan pelaksanaan gerakan literasi dalam mengoptimalkan potensi dan prestasi peserta didik di sekolah?

\section{Tujuan}

Tujuan dari gerakan literasi dalam mengoptimalkan potensi dan prestasi peserta didik di Sekolah sebagai berikut :

1. Mendeskripsikan pelaksanaan gerakan pengembangan literasi dalam mengoptimalkan potensi dan prestasi peserta didik di sekolah.

2. Mengidentifikasikan kendala dan faktor pendukung penerapan gerakan pengembangan literasi dalam mengoptimalkan potensi dan prestasi peserta didik di sekolah.

3. Mengidentifikasikan faktor pendukung penerapan gerakan pengembangan literasi dalam mengoptimalkan potensi dan prestasi peserta didik di sekolah.

4. Mendeskripsikan alternatif pengembangan pelaksanaan gerakan literasi dalam mengoptimalkan potensi dan prestasi peserta didik di sekolah.

\section{Manfaat}

Manfaat dari Gerakan Pengembangan Literasi dalam mengoptimalkan potensi dan prestasi peserta didik di Sekolah sebagai berikut :

1. Sekolah, dapat menjadi informasi dan masukan untuk pengembangan dan penguatan literasi dalam meningkatkan prestasi sekolah, guru dan peserta didik.

2. Dinas Pendidikan, dapat dijadikan sebagai pilot project bagi sekolah sekolah lain yang ingin mengembangkan literasi dan pengembangan literasi kedepannya.

3. Sekolah lain, bisa menjadi solusi alternatif dalam mengembangkan literasi untuk meningkatkan prestasi sekolah.

\section{METODE PENELITIAN}

\section{A. Jenis Penelitian}

Penelitian ini merupakan karya tulis yang berbentuk makalah atau paper yang menggunakan pendekatan ex post facto. Sudjana dan Ibrahim (2007: 60) mengatakan bahwa pendekatan ex post facto dimulai dengan mendeskripsikan situasi sekarang yang diasumsikan sebagai akibat dari faktorfaktor yang telah terjadi atau bereaksi sebelumnya. Dengan demikian, peneliti harus menoleh ke belakang untuk 
menentukan faktor-faktor yang diasumsikan penyebab, yang telah beroperasi pada masa lalu.

Dalam konteks ini penulis melakukan analisis mengenai pelaksanaan gerakan literasi di sekolah dalam mengoptimalkan potensi dan prestasi peserta didik di Sekolah yang terdiri atas lima bagian, yakni pendahuluan, landasan teori dan kerangka berpikir, metodologi penelitian, pembahasan, kesimpulan dan rekomendasi.

\section{B. Metode Pengumpulan Data}

Metode pengumpulan data dalam penulisan makalah ini terdiri atas: (1) Studi dokumentasi, dilakukan dengan menganalisis dokumen dan profil tentang pelaksanaan gerakan literasi di SMA Negeri 1 Gantung; serta (2) Studi pustaka, dilakukan dengan membaca buku-buku referensi, artikel, dan UndangUndang/peraturan terkait dengan pengembangan Gerakan Literasi di Sekolah.

\section{Analisis}

Analisis dilakukan dengan menyusun laporan secara deskriptif kuantitatif terhadap penerapan gerakan literasi dilihat dari: (1) Program dan budaya literasi;

Ketersediaan sarana dan prasarana; (3)

Komitmen dari berbagai pihak; serta (4)

Pemberdayaan sumber daya manusia.

\section{III.HASIL PENELITIAN DAN PEMBAHASAN}

\section{A. Strategi Pemecahan Masalah}

Strategi pemecahan masalah yang dipilih adalah perakan pengembangan Literasi sebagai alternatif pemecahan masalah dalam mengoptimalkan potensi dan prestasi peserta didik di Sekolah. Fokus utama gerakan pengembangan literasi yaitu memberdayakan semua stakeholders sekolah dalam kegiatan sehari hari dengan mengalokasikan sumber daya pendidikan yang ada untuk mengoptimalkan poteni dalam meraih prestasi peserta didik serta mewujudkan visi,misi dan tujuan sekolah.

Tahapan operasional gerakan pengembangan literasi dilakukan dengan langkah langkah sebagai berikut:

1. Gerakan penembangan literasi dilaksanakan dengan mengembangkan iklim literasi di sekolah.

a. Pengembangan dan penguatan literasi menjadi sebuah gerakan dan aksi nyata Membentuk tim literasi sekolah (gerakan literasi di Sekolah diorganisasikan oleh tim literasi sekolah yang terdiri dari Kepala sekolah, wakil, kepala perpustakaan, staf sarana prasarana, guru bahasa, dan tenaga kependidikan).

Melakukan koordinasi dan sosialisasi kepada orang tua 
peserta didik, sedangkan kepada peserta didik baru melalui kegiatan Masa Orientasi Peserta didik.

b. Membentuk Satuan Tugas (satgas) literasi di sekolah (menjalin kerjasama dengan (dinas pendidikan, dinas komunikasi dan informasi, perpustakaan daerah, penerbit dan dunia usaha), mengoptimalkan sumbangan buku dari para donatur, optimalisasi peran perpustakaan, menyediakan oase baca yang nyaman dengan koleksi buku non pelajaran di manfaatkan untuk berbagai kegiatan literasi, menyelenggarakan bazaar buku serta menyediakan media baca lewat majalah dinding permata pelajaran.

c. Menyelenggarakan kegiatan ekstrakulikuler yang mendukung kecakapan literasi (klub film, klub fotografi, klub jurnalis, klub olahraga serta klub tari dan seni tradisional) (Wiedarti, 2017).

d. Membentuk kelas literasi (mengundang narasumber untuk memberikan materi tentang (puisi, cerpen, novel, penulisan buku dan lainnya), mendatangkan motivator untuk membangkitkan keinginan untuk menulis dan berkarya, jumpa penulis dan talk show, bedah buku).

e. Mendokumentasikan karya peserta didik di museum literasi di sekolah (mengarsipkan dan memamerkan hasil karya peserta didik yang berhubungan dengan literasi dengan mengundang orang tua peserta didik dan berbagai pihak untuk mengetahui produk literasi yang dihasilkan.

f. Apresiasi kepada guru, peserta didik dan tenaga pendidik yang menunjukkan kesungguhan untuk mengembangkan literasi (dalam bentuk penghargaaan /Award, serta duta literasi).

2. Menjalin komunikasi dan sinergitas dengan berbagai pihak, baik di lingkungan sekolah (kepala sekolah, guru, peserta didik, pustakawan, orang tua) maupun luar sekolah (dinas pendidikan, masyarakat serta dunia usaha/industri, kantor perpustakaan daerah, dinas komunikasi dan informasi serta media massa).

3. Membangun komitmen bersama untuk mencapai prestasi baik akademik maupun non akademik dengan cara menumbuhkan harapan prestasi tinggi (mengadakan berbagai 
lomba dalam kegiatan class meeting,mendorong peserta didik untuk mengikuti berbagai lomba, memiliki komitmen dan motivasi yang kuat untuk berprestasi) serta menumbuhkan kemauan untuk berubah (mengikutsertakan guru dan peserta didik) untuk terus berkarya dan berprestasi.

B. Kendala yang Dihadapi Dalam Penerapan Gerakan Literasi

Adapun kendala-kendala yang dihadapi dalam melaksanakan gerakan pengembangan literasi diantaranya :

1. Keterbatasan dana, masih adanya beberapa program pengembangan dan penguatan literasi yang belum terealisasi.Solusi yang diambil dengan menjalin kemitraan dengan dunia usaha dan dunia industri serta para donatur.

2. Mind set untuk berubah tidak dibarengi dengan kesiapan stakeholder untuk bergerak secara cepat. Untuk mengatasi hal tersebut solusi yang diambil dengan selalu saling memotivasi dan senantiasa saling mengingatkan akan tujuan mulia dan hasil yang akan di capai dari program gerakan literasi dengan selalu berpikiran positif.

3. Masih adanya orang tua peserta didik yang belum terbiasa berkontribusi (dana) terlebih bagi yang tidak mampu dikarenakan orang tua peserta didik sebagian besar bergantung pada sektor tambang yang penghasilannya fluktuatif. Solusi yang ditempuh untuk mengatasi hal tersebut dengan sistem subsidi silang. Peserta didik yang orang tuanya mampu untuk membantu peserta didik yang orang tuanya tidak mampu. Sekolah membebaskan bagi peserta didik yang tidak mampu dari segi pembiayaan dan hanya mengharapkan partisipasi aktif dalam melaksanakan program gerakan literasi.

4. Ditemukan ada sekolompok kecil pendidik dan tenaga kependidikan yang belum maksimal berpartisipasi menjalan program gerakan literasi ini dikarenakan kurangnya komunikasi dan rendahnya keingginan untuk bertanya termasuk belum terbiasa untuk berani mengajukan usul atau gagasan. Untuk mengatasi hal tersebut sekolah selalu melibatkan stakeholders dalam kegiatan dengan membagi tugas dan memonitor kegiatan mulai dari tahap perencanaan, pelaksanaan, sampai evaluasi.

5. Komitmen, kerjasama dan kepedulian, serta kesadaran pendidik dan tenaga kependidikan 
tidak semuanya tinggi sehingga ada beberapa program gerakannliterasi yang lambat terlaksana. Alternatif yang ditempuh dengan cara mengontrol setiap perkembangan pekerjaan dan dengan senantiasa tidak henti hentinya mengingatkan akan target waktu dan target tujuan yang akan dicapai.

\section{Faktor yang Mendukung Pelaksanaan} Gerakan Literasi

Beberapa faktor pendukung terlaksananya gerakan pengembangan literasi diantaranya :

1. Sekolah memiliki team work yang kompak dan dinamis, yang di perkuat dengan tenaga pendidik dan kependidikan yang berusia relatif muda sehingga menjadi daya dukung untuk percepatan program yang digulirkan.

2. Tingginya keinginan dan motivasi peserta didik untuk terus berkembang dan berkarya serta berprestasi untuk pengembangan potensi diri dan membanggakan almamater.

3. Kepala sekolah, guru, dan tenaga pendidikan memiliki kompetensi dan dedikasi tinggi untuk mewujudkan pendidikan yang berkualitas.

4. Adanya bantuan pemerintah pusat untuk mendukung pengembangan mutu sekolah dan aktivitas belajar mengajar di sekolah.

5. Terjalinnya kemitraan yang baik antara pihak sekolah dengan instansi pemerintah daerah dan swasta serta dengan sekolah lain.

6. Komite sekolah sangat mendukung setiap program yang dibuat sekolah, sehinggamemudahkan sekolah dalam mengembangkan sumber daya secara optimal.

7. Kepercayaan, Kepedulian dan perhatian serta motivasi kuat dari dinas pendidikan dan pengawas sekolah untuk memacu pihak sekolah untuk senantiasi berkreasi dan berprestasi.

\section{Alternatif Pengembangan Pelaksanaan Gerakan Literasi}

Alternatif pengembangan ke depan adalah memantapkan gerakan pengembangan literasi sebagai program unggulan dengan strategi sebagai berikut :

1. Penerbitan buku karya peserta didik, pendidik, dan tenaga pendidikan secara berkala agar kontinuitas pengembangan budaya literasi terus terjaga serta menjadi motivasi bagi yang lainnya untuk terus berkarya dan berprestasi.Kelas literasi, museum literasi, dan kelas inspirasidapat dimanfaatkan untuk melahirkan penulis, novelis, dan peneliti. 
2. Mengoptimalkan pemanfaatan IT untuk mendesiminasikan hasil karya seluruh stakeholders dengan pembuatan web, blog, instagram dan lainnya agar hasil karya stakeholders bisa di akses bukan hanya oleh internal sekolah saja tapi juga oleh pihak lain sehingga spirit membumikan literasi di kalangan dunia pendidikan tercipta.

3. Membentuk komunitas sekolah untuk mengembangkan dan memperkuat literasi dan prestasi. Bentuk komunitas sekolah yang mungkin bisa dibentuk meliputi book lover club, science project program club (olimpiade), ICT program club (pengembangan), klub penulis, desain club (paint dan busana), enterpreneur club (klub wirausaha), language club (klub bahasa), art club (photography, traditional dance and modern), movie club, serta religius club.

4. Penyelenggaraan Gebyar Sekolah dan Festival Seni sebagai ajang aktualisasi kreasi dan inovasi peserta didik setahun dua kali dengan melibatkan partispasi dari sekolah dan pihak pemerintah, swasta lebih banyak lagi.

\section{KESIMPULAN}

Uraian pengalaman mengelola sekolah sebagaimana diuraikan pada bab-bab terdahulu dapat disimpulkan sebagai berikut

1. Tahapan Strategi gerakan pengembangan literasi dalam mengoptimalkan potensi dan prestasi peserta didik dilakukan dengan tiga prinsip utama, yakni

Pengembangan dan penguatan literasi sekolah menjadi suatu gerakan; (b) Menjalin komunikasi dan sinergitas dengan berbagai komponen; serta (c) Membangun komitmen bersama untuk berprestasi secara akademik dan non akademik.

2. Kendala yang dihadapi dalam pelaksanaan gerakan pengembangan literasi meliputi: (a) Keterbatasan dana; (b) Mind set; (c) Masih adanya orang tua peserta didik yang belum terbiasa berkontribusi;

Ditemukan ada sekolompok kecil pendidik dan tenaga kependidikan yang belum maksimal berpartisipasi; serta (e) Komitmen,kerjasama dan kepedulian serta kesadaran pendidik dan tenaga kependidikan tidak semuanya tinggi

3. Faktor pendukung terlaksananya gerakan pengembangan (gerbang) literasi di antaranya: (a) Sekolah memiliki team work yang kompak 
dan dinamis, (b) Tingginya keinginan dan motivasi peserta didik untuk terus berkembang dan berkarya serta berprestasi untuk pengembangan potensi diri dan membanggakan almamater, (c) Kepala sekolah, guru, dan tenaga pendidikan memiliki kompetensi dan dedikasi tinggi; (d) Adanya bantuan pemerintah pusat untuk mendukung pengembangan mutu sekolah dan aktivitas belajar mengajar di sekolah; (e) Terjalinnya kemitraan yang baik antara pihak sekolah dengan instansi pemerintah daerah dan swasta serta dengan sekolah lain; (f) Komite sekolah sangat mendukung setiap program yang dibuat sekolah, serta (g) Kepercayaan, Kepedulian dan perhatian serta motivasi kuat dari dinas pendidikan dan pengawas sekolah untuk memacu pihak sekolah untuk senantiasi berkreasi dan berprestasi.

4. Alternatif pengembangan ke depan dalam memgoptimalkan Gerakan Literasi sebagai program unggulan dengan strategi sebagai berikut : (a) Penerbitan buku karya peserta didik, pendidik, dan tenaga pendidikan secara berkala; (b) Mengoptimalkan pemanfaatan IT untuk mendesiminasikan hasil karya seluruh stakeholders dengan pembuatan web, blog, instagram dan lainnya; (c) Membentuk komunitas sekolah untuk mengembangkan dan memperkuat literasi dan prestasi; serta (d) Penyelenggaraan Gebyar Sekolah dan Festival Seni sebagai ajang aktualisasi kreasi dan inovasi peserta didik setahun dua kali dengan melibatkan partispasi dari sekolah dan pihak pemerintah, swasta lebih banyak lagi.

\section{DAFTAR PUSTAKA}

(1) Kementerian Pendidikan dan Kebudayaan Republik Indonesia. (2016). Desain Induk Gerakan Literasi sekolah. Dirjen Dikdasamen, Jakarta.

(2) (2016). Panduan

Gerakan Literasi Sekolah di Sekolah Menangah Atas. Dirjen Dikdasmen, Direktorat Pembinaan SMA, Jakarta.

(3) (2017). Literasi Sekolah Sebagai Sebuah Gerakan.Inspirasi dan Praktik Baik GLS di SMA Menangah Atas. Dirjen Dikdasmen, Direktorat Pembinaan SMA, Jakarta.

(4) Sudjana dan Ibrahim. (2007). Penelitian dan Penilaian Pendidikan. Sinar Baru Algensindo, Bandung.

(5) Wiedarti, P. (2017). Pelaksanaan Gerakan Literasi Sekolah. Jakarta. 